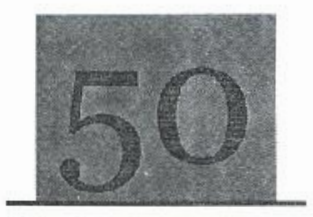

\title{
Evaluation of protein fractions of indigenous clariid fish species (Clarias gariepinus and Heterobranchus bidorsalis) and their reciprocal hybrids
}

\author{
Agbebi, O. T. / Sofela, S. O. / Awodiran, M. O.
}

\begin{abstract}
Electrophoresis of Myofibrillar and Sarcoplasmic muscle proteins of African catfish: Clarias gariepinus, Heterobranchus bidorsalis and their reciprocal hybrids in South-West Nigeria was carried out to reveal the similarities and dissimilarities among species in order to aid the selection of suitable strains for aquaculture that could lead to production of new varieties of fishes to alleviate the problem of short supply of fast growing quality fish seeds. The study was aimed at analyzing the muscle protein profiles of C. gariepinus, $H$. bidorsalis and their reciprocal hybrids. Sixteen juveniles fish samples (comprising four samples from each mating combinations) artificially propagated and reared for sixteen weeks were analyzed electrophoretically. Myofibrillar and sarcoplasmic fractions were prepared by homogenizing $150 \mathrm{mg}$ of ish muscle in $1.5 \mathrm{ml}$ of rigor buffer containing $10 \mathrm{mM}$ Trismeleates, $60 \mathrm{mM} \mathrm{KCl}, 5 \mathrm{mM} \mathrm{MgCl}, 1 \mathrm{nM} \mathrm{EDTA}$. Extracts were centrifiged in a tube at $10,000 \mathrm{~g}$ for $5 \mathrm{~min}$ al $4^{\circ} \mathrm{C}$. The resultant pellets (myofibrilla) and supernatant (sarcoplasmic) were separated using $12.5 \%$ Sodium Dodecyl-Sulphate Polyacrylamide Gel Electrophoresis (ID SDS-PAGE). The relative concentration of individual protein bands were analyzed using TotalLab ${ }^{\mathrm{TM}}$ ID software. The individual protein bands in the electrophoregram were identified in relation to their molecular weights. A tolal of eleven and seven protein bands were resolved in Myofibrilla and Sarcoplasmic fractions respectively. The 5 th band with molecular weight (MW) of $52.23 \mathrm{KD}$ a of the myofibrilla electrophoregram distinguished $C$. gariepimus from H. bidorsalis while the 3rd band with MW 119.04, 4th band with MWs 101.49 \& 102.13; 8th band with MWs 29.24 and $29.39 \mathrm{KDa}$ distinct the pure breeds from the hybrids. However, in sarcoplasmic fraction, the 3rd and 5th bands with MWs $92.11 \mathrm{KDa}$ and $54.28 \mathrm{KD}$ a respectively distinguished the hybrids in the while the 7 th band with $M W 41.67 \mathrm{KD}$ a distinct the pure breeds. Therefore, this research will serve as a bridge hetween the existing gaps of information available on the muscle protein profile of $C$. gariepinus, $H$. bidorsalis and their reciprocal hybrids and the study identifies the proteomic classification of Clariid species with the aim of enlightening fish researchers and aquaculturist on the characterization of broodstock selection for successful breeding exercise.
\end{abstract}

Keywords: Myofibrillar, sarcoplasmic, rigor buffer, C. gariepimus and H. bidorsalis.

\section{Introduction}

$\mathrm{C}$ lariids are widely considered as an important tropical catfish species for aquaculture. It is well known in both culture and artisanal environments in Nigeria where it serves both socio-cultural and research purposes in most regions. Clarias gariepinus and Heterobranchus bidorsalis are species of high aquaculture importance in South-Western Nigeria (Oyebola et al., 2013). They are widely cultured owing to their high market price, fast growth rate and ability to withstand adverse pond conditions especially low oxygen content (Idodo-Umeh, 2003). C. gariepinus and its hybrid, which is reproductively viable, are cultured throughout Nigeria and most especially in the South Western Zone. Hybridization between the two species is common and widely reported among farmers in order to improve quality of fish seed. Hybrids of the two species must be properly identified so as not to replace them with the pure of Heterobranchus spp. Intergeneric hybrids of Heterobranchus X Clarias have been observed to be fertile (Aluko 1998). It was stated that aquaculture practitioners in Nigeria have exploited the fertility of the Fl hybrids by using these hybrids as breeders for further propagation. This improper hatchery practice of indiscriminate use of F1 hybrids as breeders should be of immediate concern to conservationist and geneticists as the potential hazards of this process on the catfish gene pool: could be the genetic loss of pure indigenous stock of Heterobranchus and Clarias species (Yisa and Olufeagba, 2005). 
In the past, the identification of fish species was carried out mainly by examining the external morphological characteristics. In the present day, electrophoresis of whole muscle protein, sarcoplasmic proteins, serum proteins, liver proteins, salivary proteins and a number of enzymes often have been used by some researchers as an aid in the species identification of fish (Pinero et al. 2001, Yilmaaz et al. 2007, Lamy et al 2008). Although a few serum electrophoresis research (Diyaware et al. (2011, 2012); Akinwande et al. (2012), Majolagbe et al. (2012) and Oyebola et al. (2013)) on Clarias and Heterobrachus $s p$ have recently surfaced, but there appears dearth of information on the fish muscle protein of Clariid species in Nigeria (Agbebi et al., 2013)

Muscle is the principal component of meat and contains water, proteins, fat, carbohydrates and inorganic constituents (Forrest et al., 1975). Water, as a major constituent, accounts for 65 to $80 \%$ of the total muscle weight- Proteins comprise from 16 to $22 \%$ of the total muscle mass and are the principal component of the solid matter. Muscle proteins are generally categorised as described by Huss, (1995) as structural proteins (myofibrillar), sarcoplasmic and collagen. Myofibrillar proteins (actin, myosin, torpormyosin and actomyosin) constitute 70-80 percent of the total protein content, sareoplasmic proteins (myoalbumin, globulin and enzymes) constitute 25-30 percent of the protein while connective tissue proteins (collagen), constitute approximately 3 percent of the protein in teleostei. Myofibrillar proteins are soluble in neutral salt solutions of fairly high ionic strength $(0.5 \mathrm{M})$ while sarcoplasmic which are soluble in neutral salt solutions of low ionic strength $(<0.15$ M). Their solubility in the various concentrations of salt solutions makes them independently separable in electrophoresis.

In 1D-Electrophoresis, myofibrillar and sarcoplasmic proteins are separated on polyacrylarnide gel. Most of the electrophoretic studies carried out are related to either total proteins or myofibrillar protein or corneal proteins (Myla ct al., 2013). However, the proteins in the sarcoplasmic fraction are excellently suited to distinguishing fish species, as each species has a characteristic band pattern when separated by isoelectric methods (Huss, 1995). Therefore this research will serve as a bridge between the existing gaps of information available on the muscle protein profile of C. gariepinus, H. bidorsalis and their reciprocal hybrids and also establish the similarities and dissimilarities between the species and their hybrids for the purpose of identification.

\section{Materials and Methods}

Muscle sample collection. The experimental fish was produce through intergeneric hybridization between $\mathrm{C}$. gariepinus and H. bidorsalis obtained from Hepa Fish Farm, Asero, Abeokuta, Nigeria. The following crosses were carried out for parental cross- $C$. gariepinus $\times$ C. gariepinus and $H$. bidorsalis $\times$ H. bidorsalis, and hybrids $C$ gariepinus $\mathrm{x} H$. bidorsalis -(Clariabranchus) and H. bidorsalis $\mathrm{x}$ C. gariepinus (Heteroclarias).

Sixteen juvenile fish samples (comprising four samples from each mating combinations) were transported live in well open plastic rubber bowls to the Biotechnology laboratory unit of the Animal Breeding and Genetics of the Federal University of Agriculture, Abeokuta. Muscle were isolated from the epiaxial muscle in the region below the cranial to the dorsal fin, above the lateral line of the experimental fish with the aid of a new surgical blade for each species (El-Serafy et al., 2006 and Reedish el al., 2008) after fish killing by medullar transaction (El-Serafy et al., 2006). Myofibrillar and sarcoplasmic extracts were prepared by homogenizing $150 \mathrm{mg}$ of muscle with the aid of a mortar and pestle (on ice) in $1.5 \mathrm{ml}$ of rigor buffer containing $10 \mathrm{~mm}$ trismeleates, $60 \mathrm{mM} \mathrm{K} \mathrm{Cl}, 5 \mathrm{mM} \mathrm{MgCl}, 1 \mathrm{nM}$ EDTA (Agbebi et al., 2013). The extracts were prepared according to (Agbebi et al., 2013)

Sample preparation for SDS-PAGE analysis and gel staining. Protein fractions were centrifuged for 5 minutes at $10,000 \times \mathrm{g}$ at room temperature prior the electrophoretic analysis. Samples were loaded into $1 \mathrm{~mm} \times 12 \mathrm{~cm} \times 14 \mathrm{~cm} 12.5 \%$ polyacrylamide gel with $3 \%$ stacking gel. First, gel capillary chamber was loaded with a broad range molecular weight standard (BioRad Laboratories, Hercules, CA). Proteins were separated by applying constant voltage of $300 \mathrm{~V}$ for $2 \mathrm{hrs} 30 \mathrm{mins}$ until the dye front reached the bottom of the gel. After electrophoretic separation, gels were stained overnight with gentle agitation on an orbital shaker. Staining buffer contains ( $400 \mathrm{ml}$ methanol, $50 \mathrm{ml}$ glacial acetic acid and Coomassie Brilliant Blue $\mathrm{G} 250$ ) and subsequently destained with $10 \%$ acetic acid. Images were digitized and acquired employing a CCD camera (Samsung ES25- Samsung Opto, Electronics Co. Ltd). Raw images were subsequently imported into TotalLab 1D software (Nonlinear Dynamics, Newsacastle upon Tyne, UK) and analyzed (band detection and molecular weight calculations). User defined parameters employed are background subtraction rolling ball, radius $=300$; band detection: minimum slope $=30$; noise reduction $=3 ; \%$ maximum peak $=1.0$; Gaussian volumes fitted to peaks-no advanced fitting; $R f$ calibration aligned with no lane, and use curve lines and snap $R_{\mathrm{f}}$ lines to bands were checked (Reddish et al., 2008). 


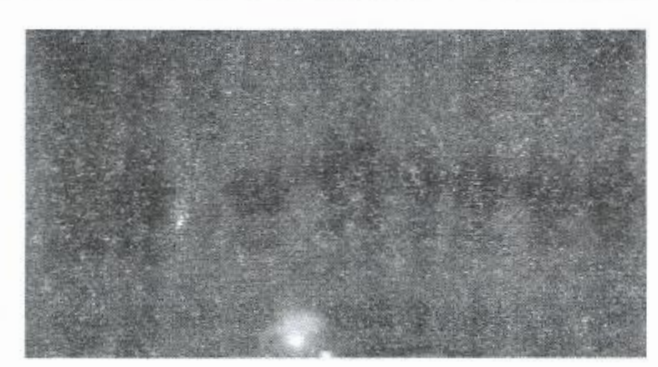

Fig. 1: Raw image of $12.5 \%$ SDS myofibrillar muscle protein of artificially propagated C.gariepinus, $H$. bidorsalis and their reciprocal hybrids.

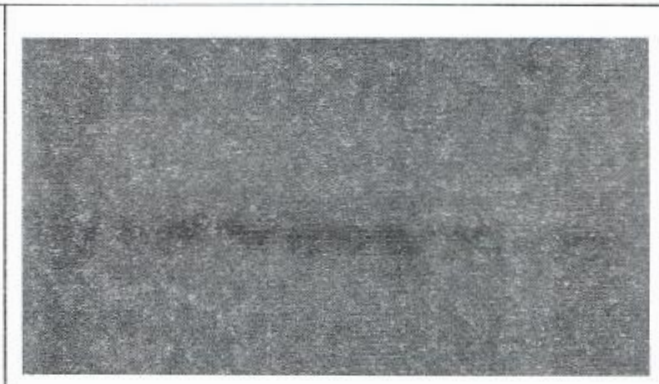

Fig. 2: Raw Image of $12.5 \%$ SDS sarcoplasmic muscle protein fraclion of artificially propagated $\mathrm{C}$. gariepinus, $\mathrm{H}$. bidorsalis and their reciprocal hybrids.

Fig. 1 \& 2 are the raw image of Myofibrilla and Sarcoplasmic muscle proteins of C. gariepinus, H. bidorsalis and their reciprocal hybrids. Results

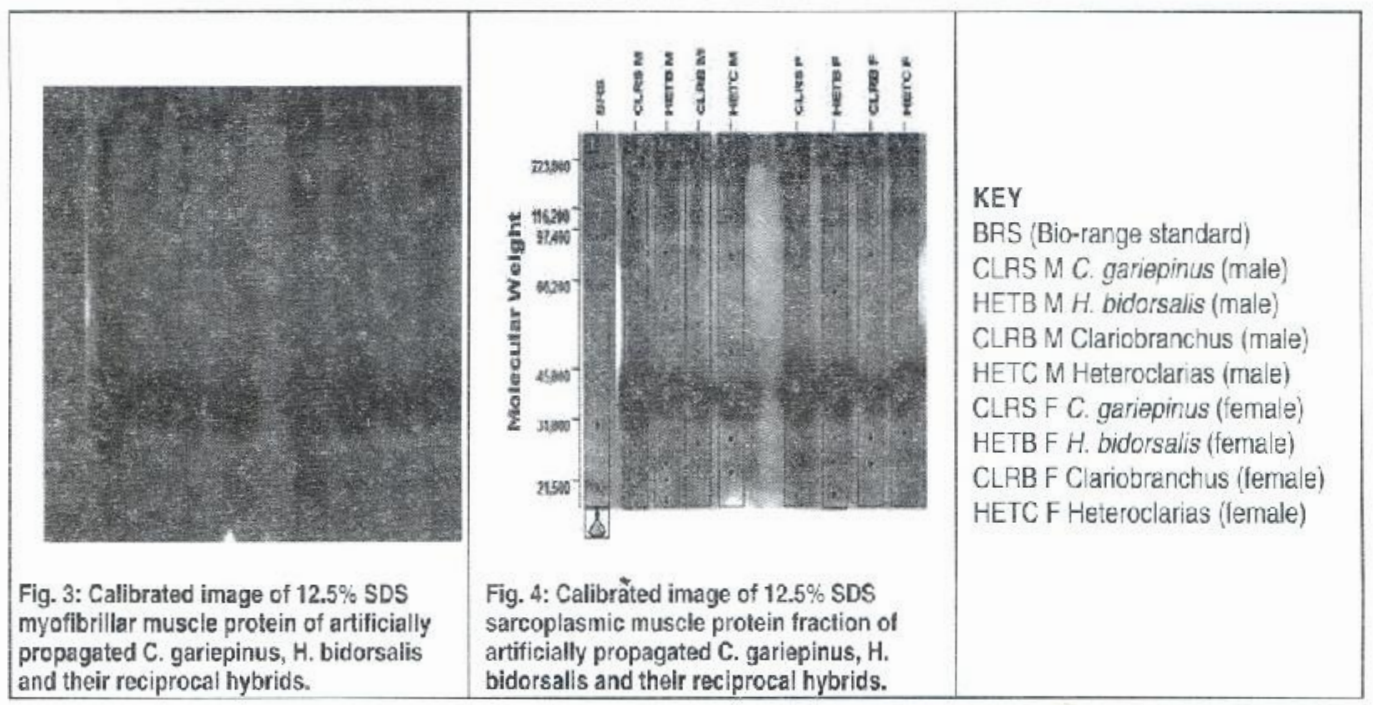

Fig. $3 \& 4$ shows the result of $12.5 \%$ SDS electrophoregram analysis. The blue diamonds denotes bands derived from electrophoregram by the TotalLab software.

The myofibrillar muscle fraction resolved a total of eleven different protein bands across the gel. The average number of protein bands resolved among the pure breeds; $C$. gariepinus and H. bidorsalis were ten and nine respectively in all examined species. In the hybrids; Clariobranchus and Heteroclarias ten protein bands each were detected. The 1st, 2nd, 6th, 7 th, 9 th, 10 th and 11 th bands were commonly detected across all mating combinations. In C. gariepinus the 5th band was present but absent in $H$. hidorsalis. The 4 th and 8 th bands were also present in the pure breeds but absent in the hybrids. The hybrids also had the 3 rd band present but absent in the pure breeds. There were no distinguishing bands between the hybrids in myofibrilla fractions.

In the malc pure breeds, eight protein bands were resolved for both C. gariepimus and H. bidorsalis while the male hybrids Clariobranchus spp. and Heteroclarias spp. both resolved six bands. In the female seven protein bands were resolved in both pure breeds; C. gariepinus and 11. bidorsalis and hybrids; Clariobranchus species and Heteroclarias spp. resolved. Although there were species specific bands among individual species there was no clear sexual dimorphic band across the male or female species of all cross combinations.

The sarcoplasmic muscle fraction resolved a total of nine different protein bands were resolved across the gel. The 1st and 9th bands were only present in BRS (Broad Range Standard) therefore, seven protein bands were detected across the mating combinations. The 2 nd, 4 th, 6 th and 8 th bands were commonly detected across all mating combinations. The average number of protein bands resolved among the pure breeds; C. gariepinus and $H$. bidorsalis were six and five respectively in all examined species. In C. gariepinus the 7th band was present but absent in both $H$. bidorsalis. In the hybrids; Clariobranchus and Heteroclarias, an average number of six and four protein bands each were respectively detected. The $3 \mathrm{rd}$ and 5 th bands were present in Clariobranchus but absent in Heteroclarias. 
In the male pure breeds, five protein bands were resolved for both $C$. gariepinus and $H$. bidorsalis while the male hybrids; Clariobranchus and Heteroclarias species resolved five and four protcin bands respectively. In the females, five protein bands were resolved in pure breeds; C. gariepinus and $H$. bidorsalis while three protein bands were resolved in hybrids Clariobranchus and Heteroclarias species.

The molecular weights of each Myofibrillar (Table 1) and Sarcoplasmic (Table 2) are presented below for artificially propagated Clarias gariepinus, Heterobranchus bidorsalis and their reciprocal hybrids in Kilo-Daltons (KDa). Myofibrillar protein bands were within $210 \mathrm{KDa}$ to $10 \mathrm{KDa}$ while the sarcoplasmic protein bands were within $140 \mathrm{KDa}$ to $30 \mathrm{KDa}$.

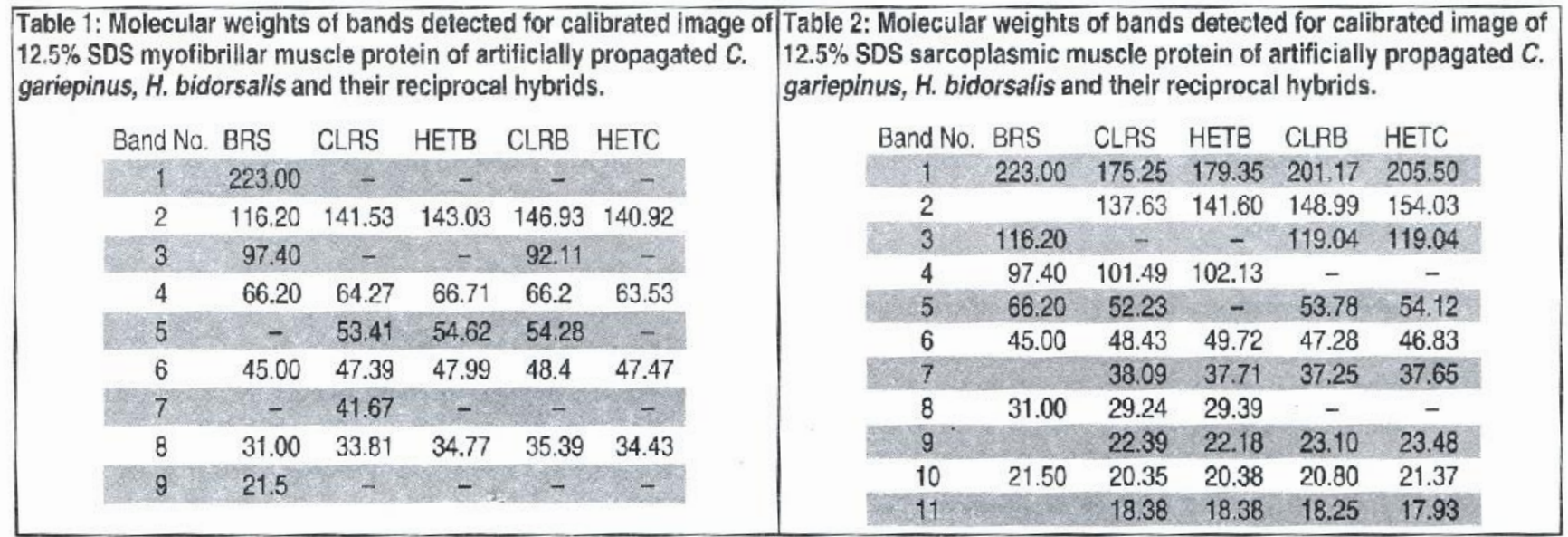

In the myofibrillar electrophoregram, the 5 th band that distinguishes the pure breeds; $C$. gariepinus and H. bidorsaiis had a molecular weight of $52.23 \mathrm{KDa}$. The distinctions between the pure breeds and the hybrids marked by the 4 th band had molecular weights 101.49 and $102.13 \mathrm{KDa}$ while the 8th band had molecular weights 29.24 and $29.39 \mathrm{KDa}$ for C. gariepimus and H. bidorsalis respectively. The 3rd band had the molecular weights 119.04 in both Clariabranchus and Heteroclarias.

In the Sarcoplasmic electrophoregram, the 7 th hand that distinguishes the pure breeds; $C$. gariepinus and $H$. bidorsalis had the molecular weight $41.67 \mathrm{KDa}$. The $3^{\text {rd }}$ and $5^{\text {th }}$ bands that distinet the hybrids; Clariabranchus and Heteroclarias had the molccular weight $92.11 \mathrm{KD}$ a and $54.28 \mathrm{KDa}$ respectively.

\section{Discussion}

Electrophoretic separation by SDS-PAGE muscie myofibrilla and sarcoplasmic proteins reveal similarity and dissimilarity among C. gariepinus, H. bidorsatis and their reciprocal hybrids in southwest Nigeria based on presence or absence and molecular weights of proteins bands of individual species and their hybrids. A total of eleven and seven protein bands were resolved in myofibrilla and sarcoplasmic fractions respectively. This is not farfetched from results obtained by Machado and Sgarbieri (1991), in the partial characterization and nutritive value of proteins from Pacu (Colossoma mitrei, Berg 1895).

Dissimilarities among species are important for identification of the species within the genus. The 5 th band of the myofibrilla electrophoregram distuinguished $C$. gariepinus from $H$. bidorsalis while the $3 \mathrm{rd}$, 4th and 8 th bands distinct the pure breeds from the hybrids. The bands of the hybrids were similar, hence no distinction could made for the the myofibrilla fraction. However, the 3rd and Sth bands distinguished the hybrids in the sarcoplasmic fraction, while the 7 th bands distincts the pure breeds. Band similarity was high in both fractions; seven out of eleven in the myofibrilla fraction and four out of seven in sarcoplasmic fraction. Myofibrillar and sarcoplasmic protein bands were found within molecular weight ranges of 10 $\mathrm{KDa}-210 \mathrm{KDa}$ of $30 \mathrm{KDa}-140 \mathrm{KDa}$. It is therefore observed that both fractions: sarcoplasmic and myofibrilla effectivdly characterized the pure breeds but sarcoplasmic identifies hybrids species effectively than myofibrilla fractions. This is in support with Yarmohammadi et al, (2011) using molecuiar technique such as amplified fragment length polymorphism (AFLP) applied to species identification of better hybrids. Hybrids identification was performed by comparison of electrophoresis profiles with parental species.

Agbebi et al. (2013) identified the individual protein bands in each fraction of yellow perch (Perca flavescens) whole muscle, sarcoplasmic and myofibrilla in relation to their molecular weights and identified the sarcoplasmic protein in the whole muscle from myotibrilla fraction. In Myla et al. (2013) muscle albumin proteins of three species of pomfrets - Pampus argenteus, $P$. chinensis and Apolectis niger observed difference betwcen the sexes of three species using protein fraction, relative mobility and molecular weights. The finding does not corvbonated with this result for no distinct classification is derived from the sexes of the two fractions. Even though sexually dimorphic band are not satisfactorily reported in this study, but male and fernale fish species are easily distinguished from one another under field examination after they are about $10 \mathrm{~cm}$ long (Yisa and Olufeagba, 2005).

\section{Conclusion}

The challenges of morphological variations in C. gariepinus, H. bidorsalis and their reciprocal hybrids necessitated the use of molecular tool in establishing their biochemical relationship. This research will enable Aquaculturists to recognize or identify the right species to use in breeding and genetic studies for accurate results and profitability. Consequently solving the problem 
of poor growth performance and loss of pure indigenous stock of Heterobranchus and Clarias species.

\section{REFERENCES}

Agbebi O.T, Wick M.P, Popovski Z. T (2013). Evaluation of three protein fractions in yellow fish perch species (Perca flavescens) using two extraction buffers: Trichloroacetic Acid Precipitation and Rigor Buffer. Ife Journal of Science Vol. 15(2): 197-208.

Akinwande A. A., O. A. Fagbenro and O. T. Adebayo (2012). Serum protein pattern in interspecific and intergeneric hybrids of Heterobranchuslongifis, Clarias gariepinus and Clarias anguillarisin sodium dodecyl sulphatepolyacrylamide gel electrophoresis (SDS-PAGE)International Journal of Fisheries and Aquaculture Vol. 4(10):202-208.

Aluko, P. O. and Shaba, M. (1998). Intra-and interspecific hybridization studies between exotic Clarias gariepinus and two indigenous Clariid species. Nigerian J. genet: 14:59-63.

Diyaware, M. Y., Haruna, A. B., Abubakar, K. A., Omitogun, G. O. (2011). Serum protein characterization of intergeneric hybrids between $C$. anguillaris X H. bidorsallis and their hybribs from semi-arid zones of Nigeria. J. Microbiol. Biotech. Res. $1 / 4: 227-234$

, Haruna, A. B., Abubakar, K. A., Omitogun, G. O. (2012). Serum protein electrophoretic characterization of C. anguillaris, H. bidorsalis and their hybrids from Northeast Nigeria. J. Microbiol. Biotech. Res. 2/1:70-77.

Huss, H. H. (1995). Quality and quality changes in fresh fish. FAO Fisheries Technical Paper 348.

Idodo-Umeh, G. (2003). Freshwater Fishes of Nigeria (Taxonomy, Ecological Notes, Diets and Utilization). Benin City: Idodo-Umeh Publishers Ltd. 232.

Lamy E, Gonçalo da Costa, Fernando, C. S., Potes, J., Coelho, A. V., Baptista, E. S. (2008). Comparison of electrophoretic protein profiles from sheep and goat parotid saliva. J. Chem. Ecol. 34:388-397.

Majolagbe, F. A., Awodiran, M. O., Awopetu, J. (2012). Electrophoretic Studies of Clurias gariepinus and Heterobranchus bidorsalis and their hybrids. Ife Journal of Science 14:1 167.

Myla, S., Chakravarty, M., Navya, P. R., Ganesh, C. (2013). SDS-polyacrylamide gel electrophoresis of muscle albumin proteins in three species of pomfrets-Pampus argenteus, Pampus chinensis, and Apolectis niger. International Journal of Advanced Biology. 3/2: $172-180$.

!

Oyebola, O. O., Omitoyin, B. O., Salaku, A. E., Ajani, E. K., Awodiran, M. O. (2013). Genetic and biochemical differentiation of pectoral spine variants in Clarias gariepinus. Int'l J. of Modern Biol. Res. 8:14.

Pineiro, C., Vazquez, J., Marina, A. I., Barros-Velazquez, J., Gallardo, J.M. (2001). Characterization and partial sequencing of speciesspecific sarcopiasmic polypeptides from commercial hake species by mass spectrometry following two-dimensional electrophoresis. Electrophoresis. 22/8: 1545-1552.

Reddish, J. M., St.-Pierre, N., Nichols, A., Green-Church, K. (2008). Proteomic analysis of proteins associated with body mass and length in yellow perch (Perca flavescens). Proteomics 2008, 8, 2333-2343.

Yilmaz, M., Yilmaz, R. H., Alas, A. (2007). An electrophoretic taxonomic study on serum proteins of Acanthobrama marmid, Leuciscus cephalus, and Chondrostoma regium. EurAsian J. of Biosciences 3, 22-27.

Yisa, M. Olufeagba, S. O. (2004). An exposition on field identification of Clariid catfishes as an important tool in fish breeding and genetics. Proceedings, 19th FISON Annual Conference, Nov. 29-Dec. 3, Horin. 